\title{
IbM Mushroom Cultivation to Empowerment Mothers Dasa Wisma
}

\author{
Yosi Laila Rahmi ${ }^{\# 1}$, Heffi Alberida ${ }^{\# 2}$, Helendra ${ }^{\# 3}$ \\ ${ }^{1,2,3}$ Staf Pengajar Jurusan Biologi FMIPA UNP \\ (Universitas Negeri Padang, Jalan Prof. Dr. Hamka, Air Tawar, Kota Padang, Indonesia) \\ * Correspondence: yosibio@fmipa.unp.ac.id
}

Diterima 6 Maret 2018, Disetujui 6 Maret 2018 Dipublikasikan Maret 2018

\begin{abstract}
Matur is one of districts in the area of Kabupaten Agam. Regional Matur having various potentials, not only in terms of geographical, tourism and the condition of its natural but also in terms of human resources, namely dasa wisma. But, data from the Central Bureau of statistics 2014 there are still the high level of poverty in Kabupaten Agam. Effort to improve family welfare could be done by empowerment ladies joining group dasa wisma. One of a valuable food high health services post nutritional supplements and this could potentially cultivated through empowerment of ibu-ibu dasa wisma is a mushroom . The cultivation of mushroom having excess as ease of getting then made into raw materials, state of the art technologies under cultivation that is relatively easy to learn, and frugally place. Activities are to be implemented devotion the public was aimed at peaceful and steady to help of family welfare, to the establishment of the ibu-ibu social preneur final communiqu of the conference wisma a partner that having their knowledge and skills about the cultivation of mushrooms and the creation of excellent product yield mushroom cultivation of being worthy of being marketed.The stage of activity can be done is coordination and socialization as with a party nagari as well as groups of the homestead final communiqu of the conference, the task of procuring and materials for mushroom cultivation and training in cultivating a mushroom .
\end{abstract}

Keywords -Cultivation, Mushroom, Empowerment, Dasawisma.

\section{Pendahuluan}

Kecamatan Matur adalah salah satu Kecamatan yang ada di wilayah Kabupaten Agam, yang terdiri dari 6 Nagari yaitu: Nagari Matur Hilir, Nagari Matur Mudik, Nagari Lawang, Nagari Panta Pauh, Nagari Parik Panjang, dan Nagari Tigo Balai. Kecamatan Matur adalah sebuah kawasan pegunungan yang subur dengan panorama lembah, ngarai dan danau yang indah. Tinggal dan berdomisili di kawasan pegunungan yang subur ini, maka secara umum mata pencaharian masyarakat Matur adalah petani padi, tebu, cabe, sayuran dan lainlainnya Sebahagian kecil masyarakat Matur memiliki usaha kuliner, selain itu masyarakat Matur dekat dengat sosio historis sebagai kawasan bekas tempat perang, yang meninggalkan beberapa bekas sejarah dan budaya
[1].

Daerah Matur memiliki berbagai potensi, tidak hanya dari segi geografis, pariwisata dan kondisi alamnya tetapi juga dari segi sumber daya manusianya. Hal ini terlihat dari pencapaian kelompok dasawisma Kecamatan Matur yang menjuarai Lomba Dasa Wisma tingkat Sumatera Barat tahun 2015. Selain itu pada awal tahun 2017 ini ketua Dasa Wisma Cempaka mewakili Kecamatan Matur mengikuti lomba Ketua Dasa Wisma Tingkat Kabupaten Agam Tahun 2017.

Dasa wisma adalah kelompok ibu-ibu yang berasal dari 10 rumah yang bertetangga. Potensi sumber daya manusia dalam hal ini kelompok dasa wisma, hendaknya memiliki peran di tengah masyarakat. Salah satu peran yang bisa dilakukan oleh kelompok dasa wisma di masyarakat adalah meningkatkan pendapatan keluarga [2]. Data dari Badan Pusat Statistik tahun 2014 tercatat masih tingginya angka 
kemiskinan di Kabupaten Agam [3]. Upaya meningkatkan kesejahteraan keluarga melalui pemberdayaan perempuan akan dilakukan dengan bekerja sama dengan menggunakan jejaring organisasi ibu-ibu dasa wisma. Hal ini dikarenakan jejaring organisasi dasa wisma sudah terorganisir secara baik. Selain itu kegiatannya juga sudah melembaga dan menjadi bagian dari kehidupan masyarakat. Dasa Wisma sebagai kelompok terkecil dari kelompok-kelompok PKK memiliki peran strategis mewujudkan keluarga sejahtera contohnya peningkatan derajat kesehatan dan gizi.

Salah satu makanan yang bernilai gizi tinggi dan berpotensi dibudidayakan melalui pemberdayaan ibu-ibu dasa wisma adalah jamur. Jamur merupakan makanan yang bergizi tinggi [4]. Kandungan lemaknya yang rendah menyebabkan jamur layak dikonsumsi, apalagi bagi yang berdiet. Jamur tiram yang teksturnya mirip dengan daging ayam merupakan makanan favorit bagi vegetarian. Kandungan nutrisi pada jamur juga terbilang lengkap. Budidaya jamur menurut [5] memanfaatkan limbah organik yang banyak melimpah, murah dan mudah didapat di sekitar kita sehingga menjadikan lingkungan bersih, indah dan sehat. Budidaya jamur tidak memerlukan lahan yang luas. (100 m2 bisa menampung \pm 7500 baglog, dengan estimasi pendapatan Rp. 200.000 per hari. Produk Jamur dapat dimanfaatkan untuk menambah gizi atau menu serta dapat menambah pendapatan keluarga. Kompos bekas media tanam dapat langsung digunakan untuk pupuk kolam ikan, makanan ikan dan untuk memelihara cacing.

Dari segi bisnis, budidaya jamur memiliki perputaran modal yang cepat. Dengan masa inkubasi selama 30 hari dan selanjutnya dapat dipanen setelah 120 hari (4 bulan) membuat usaha budidaya ini menjadi sangat menguntungkan. Di samping itu, budidaya jamur memiliki kelebihan seperti kemudahan mendapatkan bahan baku, teknologi budidaya yang relatif mudah dipelajari, memiliki resiko gagal yang kecil dan hemat tempat karena dapat memanfaatkan ruang kosong di sekitar rumah warga [6]. Akan tetapi ibu-ibu dasa wisma Cempaka Nagari Pari Panjang belum memiliki pengetahuan dan keterampilan mengenai teknik budidaya jamur, selain itu juga belum memiliki kumbung untuk rumah jamur serta peralatan dan bahan yang diperlukan untuk budidaya jamur.

\section{Solusi/Teknologi}

Metode pelaksanaan pengabdian kepada dasa wisma mitra secara ringkas dapat digambarkan dalam bentuk diagram alir sebagai berikut:

\section{PERMASALAHAN MITRA}

- Angka kemiskinan yang masih tinggi di masyarakat Kec. Matur.

- Profesi sebagian besar ibu-ibu dasa wisma sebagai ibu rumah tanga, sehingga tidak ada pemasukan tambahan bagi pendapatan keluarga.

- Belum memiliki pengetahuan dan keterampilan budidaya jamur.

- Belum memiliki rumah jamur (kumbung) sebagai tempat budidaya jamur.

- Belum memiliki peralatan dan bahan untuk budidaya jamur.

\section{METODE PENYELESAIAN MASALAH}

- Koordinasi dan sosialisasi dengan pihak nagari dan dasa wisma

- Pengadaan peralatan dan bahan untuk budidaya jamur.

- Pelatihan budidaya jamur bagi ibu-ibu dasa wisma.

- Pembuatan kumbung (rumah jamur).

- Pembuatan baglog.

\section{HASIL YANG DIHARAPKAN}

- Peningkatan kesejahteraan keluarga para anggota dasa wisma mitra.

- Terbentuknya social preneur ibu-ibu dasa wisma mitra yang memiliki pengetahuan dan Keterampilan tentang budidaya jamur

- Terciptanya produk hasil budidaya jamur yang layak dipasarkan.

Gambar 1. Diagram Alir Metode Pelaksanaan Pengabdian Masyarakat 


\section{Hasil dan Diskusi}

1. Hasil Koordinasi dan Sosialisasi dengan pihak Nagari dan Kelompok Dasa Wisma Sasaran

Setelah usulan IbM Budidaya Jamur untuk Pemberdayaan Ibu-ibu Dasa Wisma dinyatakan diterima oleh LP2M UNP, maka tim pelaksana kegiatan pengabdian masyarakat Jurusan Biologi FMIPA UNP melakukan koordinasi dan sosialisai awal dengan pihak Nagari dan kelompok dasa wisma sasaran. Kegiatan ini bertujuan untuk menginformasikan kepada pihak Nagari mengenai tujuan dan rencana kegiatan. Hasil dari kegiatan koordinasi dan sosialisasi ini menunjukkan pihak Nagari mengapresiasi kegiatan pemberdayaan ibu-ibu dasa wisma melalui pelatihan budidaya jamur. Menurut pemaparan Wali Nagari Parik Panjang, kegiatan pelatihan ini sejalan dengan Undangundang No. 6 Tahun 2014 tentang pemberdayaan masyarakat. Harapannya agar kegiatan pelatihan ini nantinya juga memberikan informasi mengenai teknik pemasaran yang baik, karena selama ini kegiatan usaha yang telah dilakukan oleh masyarakat banyak terkendala di bagian pemasaran. Sedangkan untuk lahan budidaya jamur, Wali Nagari menyampaikan Nagari Parik Panjang memilki lahan yang luas untuk lokasi budidaya jamur.

Setelah melakukan koordinasi, sosialisai dan perizinan dengan pihak Nagari, selanjutnya dilakukan kegiatan sosialisasi dengan kelompok masyarakat sasaran yaitu ibu-ibu anggota dasa wisma Cempaka Nagari Parik Panjang. Kegiatan sosialisai awal ini meliputi rencana persiapan kegiatan, lokasi pelatihan dan lokasi kumbung jamur. Hasil dari sosialisasi awal ini adalah kesepakatan mengenai pengadaan alat dan bahan untuk budidaya jamur, pembuatan kumbung jamur serta waktu pelaksanaan pelatihan budidaya jamur.
2. Kegiatan pengadaan alat dan bahan untuk budidaya jamur

a. Pembuatan Kumbung (rumah jamur)

Pembuatan kumbung jamur diawali dengan perancangan desain, kemudian dilanjutkan dengan pembelian alat dan bahan untuk pembuatan kumbung dan dilanjutkan dengan proses pembuatan kumbung. Berdasarkan hasil sosialisasi awal dengan pihak Nagari mengenai lokasi kumbung jamur telah disepakati di salah satu lahan milik warga. Kemudian beberapa orang warga yang bertugas membuat kumbung. Untuk proses pembuatan kumbung jamur memerlukan sekitar dua bulan.

b. Pengadaan baglog jamur

Untuk pengadaan baglog jamur, tim pelaksana kegiatan pengabdian masyarakat menyediakan beberapa jenis baglog jamur yaitu 1) baglog yang belum disterilisasi; 2) baglog yang sudah disterilisasi; 3) baglog yang baru ditumbuhi jamur dan 4) baglog yang sudah ditumbuhi jamur siap panen.

3. Kegiatan Pelatihan budidaya jamur bagi ibuibu dasa wisma

Kegiatan pelatihan dilaksanakan setelah kumbung jamur selesai dibuat. Kegiatan ini bertujuan untuk memberikan pemahaman secara teori kepada ibu-ibu dasa wisma mengenai teknik budidaya jamur. Kegiatan pelatihan ini dilakukan dengan metode presentasi materi oleh narasumber kemudian dilakukan diskusi dan tanya jawab. Kegiatan ini dilaksanakan pada hari Sabtu, 4 November 2017. Tempat pelaksanaan kegiatan adalah di salah satu rumah Anggota Dasa Wisma Cempaka Nagari Parik Panjang Kec. Matur. Jumlah peserta yang hadir sebanyak 26 orang.

Dalam kegiatan pelatihan budidaya jamur para peserta diberikan pengetahuan mengenai tata cara dan teknik menjadi petani atau pengusaha jamur khususnya jamur tiram, mulai dari pengolahan media tanam (baglog), pembibitan, pemeliharaan, dan tata cara panen. Dalam acara juga terjadi dialog dan tanya jawab interaktif seputar budidaya jamur yang diajukan oleh para peserta, hal ini menunjukkan peserta penyuluhan sangat antusias dan tertarik untuk menjadi petani 
maupun pengusaha jamur. Pertanyaan pertanyaan yang diajukan peserta kegiatan yang membuktikan ketertarikan peserta menjadi petani dan pengusaha jamur.

Tanggapan dari peserta kegiatan budidaya jamur yang diadakan oleh Tim Pengabdian Masyarakat Jurusan Biologi FMIPA UNP ini memberikan tanggapan positif yang dikutip dari beberapa peserta kegiatan. Ibu Ely Rosyidah (Rumah Tangga) "Acara kegiatan pengabdian masyarakat budidaya jamur jelas kegiatannya, sangat bermanfaat bagi warga setempat sebagai peserta kegiatan pengabdian masyarakat ini, untuk harapan semoga kedepannya lebih baik lagi,baik untuk Jurusan Biologi FMIPA UNP maupun warga setempat selaku peserta kegiatan dalam pemberdayaan ibu ibu Dasawisma Nagari Parik Panjang Kec. Matur Kab. Agam”. Selain itu, ibu Ria (Petani) juga memberikan tanggapan atas kegiatan ini, ia mengatakan "Acara kegiatan pengabdian masyarakat budidaya jamur bagus, budidaya jamur ini dapat dimanfaatkan dalam khidupan sehari hari, kegiatan ini dapat digunakan sebagai usaha yang membantu perekonomin warga apabila jamur ini laku dipasaran".

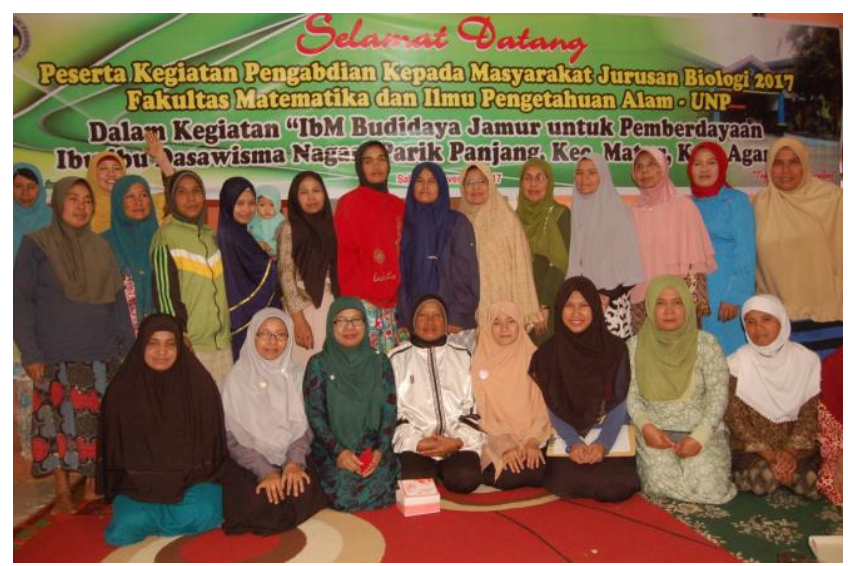

Gambar 2. Foto bersama tim pelaksana dengan ibu-ibu dasa wisma setelah pelatihan budidaya jamur

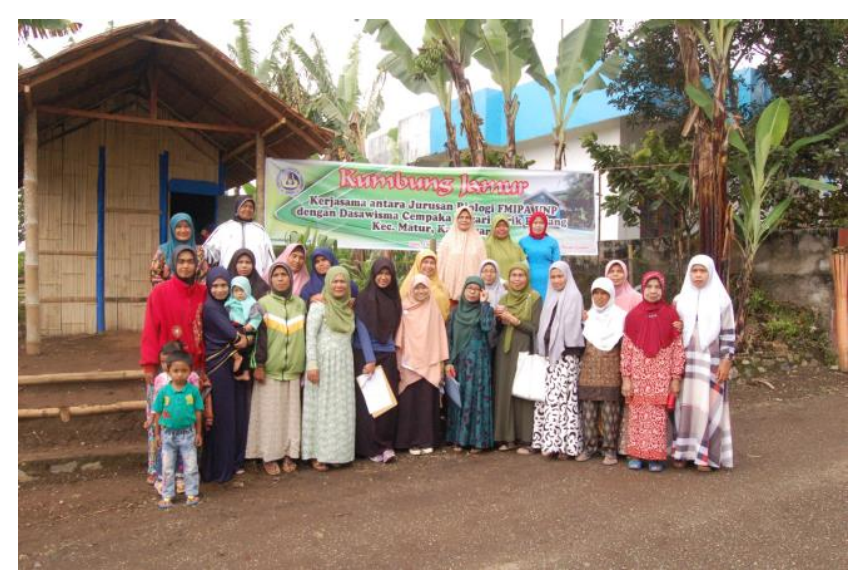

Gambar 3. Foto di depan kumbung jamur

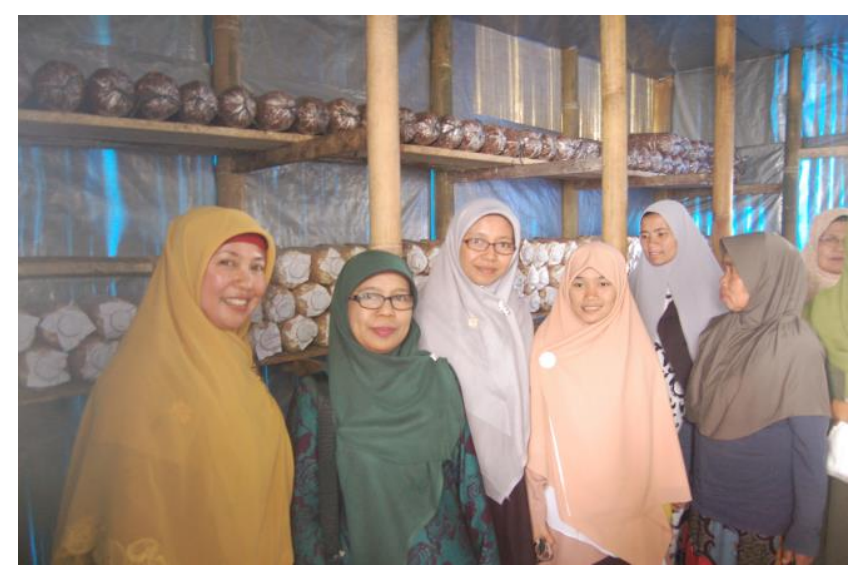

Gambar 4. Tim pelaksana di dalam kumbung jamur

Untuk hasil panen jamur tiram perdana dibagi-bagikan kepada ibu-ibu anggota dasa wisma kemudian dijual ke masyarakat umum dengan hasil penjualan sebanyak Rp. 250.000 ribu rupiah. Rentang bulan Desember 2017 dan Januari 2018 dasa wisma Cempaka memperoleh kunjungan dari Pemerintah Kecamatan, Kabupaten serta Provinsi. Produk Jamur Tiram menjadi salah satu oleh-oleh andalan dari dasa wisma Cempaka Nagari Parik Panjang.

\section{Kesimpulan}

Telah dilaksanakannya tiga tahapan kegiatan pengabdian masyarakat pelatihan budidaya jamur kepada ibu-ibu dasa wisma terlaksana dengan baik yaitu pihak Nagari Parik Panjang Kec. Matur Kab. Agam dan kelompok ibu-ibu dasa wisma Cempaka sangat mendukung kegiatan pelatihan budidaya jamur, telah dibangun kumbung jamur di salah satu lahan warga dan di dalamnya juga telah berisi baglog jamur, serta ibu-ibu anggota dasa wisma merasa 
antusias dan memperoleh pengetahuan dan keterampilan tentang budidaya jamur.

\section{Ucapan Terima Kasih}

Tim Pelaksana mengucapkan terima kasih kepada LP2M UNP yang telah mendanai kegiatan pengabdian masyarakat dalam pendanaan PNBP tahun 2017. Selain itu tim pelaksana juga mengucapkan terima kasih kepada pihak Nagari Parik Panjang serta ibu-ibu anggota dasa wisma Cempaka Kec. Matur, Kab. Agam.

\section{Pustaka}

[1] Sari, Utami Nurmala dan Ekasari, Rini. 2014. Potensi Kecamatan Matur Kabupaten Agam Menjadi Sebuah Desa Wisata. Jurusan Administrasi Niaga. Politeknik Negeri Padang.

[2] Wafiyah. 2015. Pemberdayaan Dasa Wisma sebagai Upaya Pemberlangsungan K3 (Kebersihan, Keindahan, dan Ketertiban) di Dusun Gintungan, Desa Deyangan, Kec. Mertoyudan, Kab. Magelang. Jurnal DIMAS. Volume 15, Nomor 1, Oktober 2015.

[3] Peraturan Bupati Agam Nomor 11 Tahun 2015. Rencana Kerja Pembangunan Daerah (RKPD) Kabupaten Agam Tahun 2016.

[4] Hermawan, Hedi. 2015. Teknologi Budidaya Jamur Tiram Putih (Pleurotus ostreatus).

Kelompok Peneliti dan Pengkaji Sumberdaya : BPTP Jambi.

[5] Hendro, Bambang. 2014. Pelatihan Budidaya Jamur. Yogyakarta: UGM

[6] Susilawati dan Raharjo, Budi. 2010. Petunjuk Teknis Budidaya Jamur Tiram (Pleourotus ostreatus Var florida) yang Ramah Lingkungan (Materi Pelatihan Agribisnis bagi KMPH). BPTP Sumatera Selatan. 